\title{
Compositional trends in magmatic and hydrothermal silicates of the Petráčkova hora intrusive complex, Bohemian Massif - link between the magmatic processes and intrusion-related gold mineralization
}

\author{
Jiř́i ZACHARIÁŠ
}

Institute of Geochemistry, Mineralogy and Mineral Resources, Charles University, Albertov 6, 12843 Prague 2, Czech Republic; zachar@natur.cuni.cz

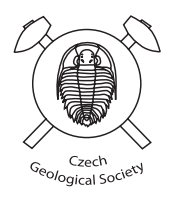

\begin{abstract}
Mineralized zones of the Variscan (348-344 Ma) Petráčkova hora gold deposit locally exhibit high-temperature ( 600 to $\sim 500{ }^{\circ} \mathrm{C}$ ) hydrothermal alterations: K-alteration-1 (selectively pervasive) and K-alteration-2 (fracture-related) in the granodiorite and granodiorite porphyries, and silicification- 1 and -2 in the country rocks (biotite hornfels and feldspathic quartzite). Alteration processes led to partial recrystallization of primary magmatic silicates, and to crystallization of new hydrothermal phases (K-feldspar, biotite and hornblende). Electron microprobe analyses were used to trace magmatic to hydrothermal evolution of the mineral chemistry.

The K-feldspar phenocrysts in the granodiorite and granodiorite porphyry exhibit complex magmatic crystallization and resorption textures. Compositionally, K-feldspars differ especially in the barium admixture. It decreases from early (5-0.8\% celsian or 2.6-0.4 wt. \% BaO; phenocrysts) to late magmatic (1.1-0 \% celsian; groundmass) and hydrothermal (1.2-0\% celsian) K-feldspars.

No significant differences were found between the chemistry of magmatic and early hydrothermal amphiboles. They all correspond to magnesiohornblende or actinolite. Tetrahedral silica $\left(\mathrm{Si}^{\mathrm{IV}}\right)$ ranges from 6.7 to 7.8 atoms per formula unit, however; values greater than 7.2 are the most common. They exhibit positive $\mathrm{Si}^{\mathrm{IV}}-\mathrm{Mg} /\left(\mathrm{Mg}+\mathrm{Fe}^{2+}\right)$ correlation. Late hydrothermal amphibole associated with silicification-2 is also magnesiohornblende; however, it exhibits negative $\mathrm{Si}^{\mathrm{IV}}-\mathrm{Mg} /\left(\mathrm{Mg}+\mathrm{Fe}^{2+}\right)$ trend.

Differences in the biotite composition are less pronounced in comparison to amphiboles and comprise especially a decrease in the Ti content and an increase in the $\mathrm{Mg} /\left(\mathrm{Mg}+\mathrm{Fe}^{2+}\right)$ ratio from the magmatic to the hydrothermal biotites. Some of the fine-grained biotite aggregates (recrystallized magmatic or hydrothermal biotite) are depleted in potassium, probably due to alteration demonstrated by the presence of submicroscopic intergrowths with clay/chlorite minerals (unrecognizable in back-scattered electron mode).

Broad similarities in the chemistry of magmatic and early hydrothermal silicate minerals support the high-temperature nature of the early hydrothermal stage, and point to probable admixture of exsolved magmatic fluid phase in the early hydrothermal fluids.
\end{abstract}

Keywords: potassic feldspar, celsian, amphibole, granodiorite, hydrothermal alterations, Central Bohemian Plutonic Complex Received: January 17, 2008; accepted April 2, 2008, handling editor J. Konopásek

\section{Introduction}

The Petráčkova hora $(\mathrm{PH})$ deposit represents a unique gold-mineralization type in the Bohemian Massif that is not only hosted by small composite granodiorite stock, but seems to be also genetically at least partly related to the evolution of an associated deep granitic magma reservoir. Multiple evidence for intimate relationships between the mineralization and the granitic system was described by Zachariáš et al. (2001) and includes: i) the spatial distribution of the mineralization; ii) the high temperature nature of gold-bearing quartz veins (590-400 ${ }^{\circ} \mathrm{C}$ ); iii) the presence of relics of supposed magmatic fluids both in the granodiorite K-feldspar phenocrysts and in the quartz veins; iv) the absence of lower temperature hydrothermal alteration envelopes around the veins and the presence of high-temperature alterations resembling those typical for porphyry systems; and v) the very similar age of the mineralization (348-344 Ma) and of the host granodiorite (348 Ma). Deposit classification, however, is not unequivocal; the mineralization shares signs of both intrusion-related (e.g. Lang and Baker 2001; Baker 2002) and orogenic gold deposits (e.g. Goldfarb et al. 2001).

One of the prominent features of the intrusion-related gold mineralization is more or less continuous transition from the magmatic to the hydrothermal stage (associated with the formation of gold-bearing quartz veins). This paper is therefore aimed at finding further evidence for the magmatic to hydrothermal transition during the early 
stages of the PH deposit evolution, based on the study of magmatic, metamorphic and hydrothermal silicate minerals.

\section{Geological setting}

The Petráckova hora deposit is located in the southern part of the Rožmitál tectonic block (RTB) of the Teplá-Barrandian Unit, about $8 \mathrm{~km}$ to the SSW of Rožmitál pod Třemšínem. Two names were used in the past for the prospect/deposit: the Petráčkova hora deposit (after a local hill) or the Vacíkov deposit (after the cadastral affiliation). The mineralization is hosted largely by composite granodiorite stock and extends to the surrounding Lower Cambrian siliciclastic metasediments. The geology, mineralogy, fluid composition and evolution as well as genetic model of the $\mathrm{PH}$ deposit were described in detail by Studničný et al. (1987, 1994), Studničná and Studničný (1995), Studničná and Zachariáš (1996) with Zachariáš et al. (2001).

The RTB (Havlíček 1977, 1992) represents a segment of moderately to weakly metamorphosed Lower Cambrian to Devonian sediments (Fig. 1) flanked by granitoids of the Central Bohemian Plutonic Complex (CBPC), particularly by the Blatná granodiorite.

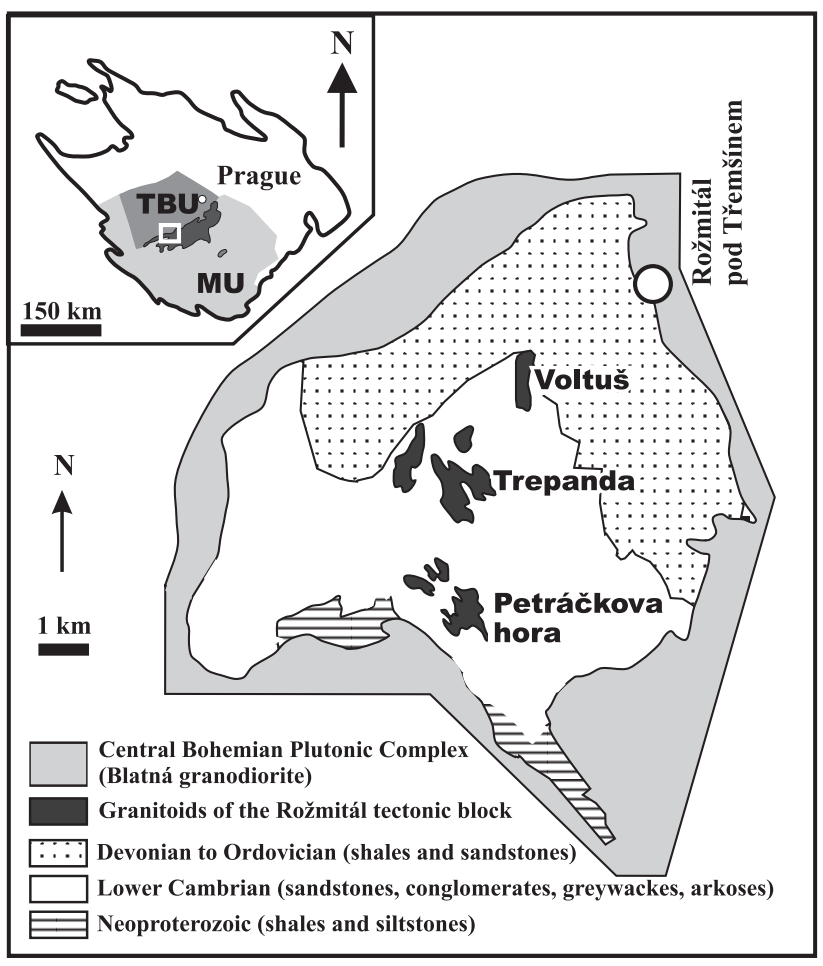

Fig. 1 Simplified geological map of the Rožmitál tectonic block (RTB) and location of individual granitoid stocks. The small inset shows outline of the Bohemian Massif, extent of the Moldanubian (MU) and TepláBarrandian (TBU) units and position of the RTB (white square).
Several isolated granitoid bodies were mapped in the past in the central and southern parts of the RTB. They were variously named and assigned either: i) to the CBPC ("hybrid granitoids" of Havlíček 1977 or "porphyritic granite of the Bělčice type" of Kettner 1952); ii) to the Rožmitál Cambrian volcanic complex ("dacites to andesites" of Drozen et al. 1986 and of Studničný et. al. 1987, 1994), or iii) were left unassigned ("foliated porphyries" of Kodym and Suk 1960).

This work benefits from a detailed underground geological survey during exploration of the PH deposit. The exploration adit allowed to recognize intrusive contacts of many granitoid rocks formerly classified as volcanic tuffs or metasomatized tuffs (mainly of dacitic composition). Finally, intrusive and hydrothermal successions were unambiguously established (Zachariáš 1998).

The PH granodiorite stock consists of the central (younger) and the peripheral (older) magmatic facies (Zachariáš et al. 2001). Frequent subvertical dykes of two subgroups of granodiorite porphyry are older than the granodiorite, while that of leucocratic granodiorite and aplite are younger. As the distinguished granitoid types differ chiefly texturally, only the volumetrically dominant "central granodiorite" is described in detail in the petrology section. Geochemically, the $\mathrm{PH}$ granodiorite is similar to the Blatna granodiorite $(346.7 \pm 1.6$ $\mathrm{Ma}$, SHRIMP U-Pb zircon dating of Janoušek et al. 2007) of the CBPC Blatna suite. Texturally, however, is different. The quartz veins (six types; $Q_{1}$ through $Q_{5}$ and $\mathrm{Q}_{\mathrm{x}}$ of unknown relative age) are even younger than the aplites. The gold content is highest in the $\mathrm{Q}_{2}$ veins (up to $70 \mathrm{~g} / \mathrm{t} \mathrm{Au})$ and decreases to the $\mathrm{Q}_{4}$ and $\mathrm{Q}_{5}$ veins $(\sim 5 \mathrm{~g} / \mathrm{t}$ $\mathrm{Au})$. The description of paragenetic relationships among gangue and ore minerals can be found in Zachariáš et al. (2001). Quartz veins are usually devoid of visible attendant hydrothermal alteration, except for $\mathrm{Q}_{1}$ veins that are bordered by $\mathrm{K}$-feldspar rich assemblage (up to $20 \mathrm{~mm}$ thick).

The RTB shows signs of polyphase deformation. A local shear zone crosscuts southern part of the PH stock, while the northern part is only weakly deformed. Ductile deformation of granodiorite porphyries and of adjacent granodiorite occurred at subsolidus conditions at temperatures of $c .450-300{ }^{\circ} \mathrm{C}$. Late quartz veins $\left(\mathrm{Q}_{5}\right)$ formed after major stress reorientation (Zachariáš 1998).

\section{Methods}

The mineral chemistry was studied using 29 polished thin sections, representing granitoids (16), hornfelses (7) and hydrothermal alteration products (6). Mineral analyses were performed using the CAMEBAX microprobe in WDS mode (15 kV voltage, counting time $10 \mathrm{~s})$ 
at the Faculty of Science, Charles University in Prague (operator J. Hovorka). Natural standards were used for the microprobe calibration. The sodium and potassium were measured first in order to minimize their loss during analysis. Back-scattered electron images were acquired using the Oxford CamScan microscope in the same laboratory.

The mineral formulae are based on $8 \mathrm{O}$ for feldspar, $11 \mathrm{O}$ for biotite and $23 \mathrm{O}$ for amphibole. The ferrousferric iron balance was estimated only for amphiboles, using the AMPH-CLASS spreadsheet (Esawi 2004). The amphibole classification is after Leake et al. (1997). The Mg-number (MG\#) was calculated as $100 \mathrm{Mg} /(\mathrm{Mg}+$ $\left.\mathrm{Fe}^{2+}\right)$ or as $100 \mathrm{Mg} /\left(\mathrm{Mg}+\mathrm{Fe}_{\text {tot }}{ }^{2+}\right)$. In total, 105 amphibole, 150 feldspar and 90 biotite analyses were performed and interpreted.

\section{Results}

\subsection{Petrology of unaltered rocks}

The Central Petráčkova Hora granodiorite corresponds to hornblende-biotite medium- to fine-grained granodiorite with more or less distinct microporphyritic texture. Average mineral proportions are: plagioclase (40 vol. \%), quartz (25-22\%), K-feldspar (20-15\%), biotite (16-13\%), and hornblende (5-2\%). White to pink/red phenocrysts of K-feldspar ( $0.5-1.5 \mathrm{~cm}$ in size) commonly enclose numerous irregularly distributed inclusions of anhedral biotite, plagioclase, and rare hornblende and quartz (Fig. 2a-c). In addition to these inclusions, the $\mathrm{K}$-feldspar phenocrysts are frequently rimmed by narrow zone containing a single line (Fig. 2d) of numerous quartz inclusions occasionally intermixed with plagioclase inclusions of similar size. Rarely, incipient graphic intergrowth (Fig. 2e) was recorded instead of line of round inclusions. Plagioclase $(0.5-1.5 \mathrm{~mm})$ is weakly zoned $\left(\mathrm{An}_{15-38}\right)$. Two textural forms of biotite are present: anhedral to subhedral coarse-grained flakes $(0.5 \pm 0.2$ $\mathrm{mm})$ and aggregates of fine-grained biotite $(\sim 0.02 \mathrm{~mm})$. Hornblende $(0.5-1.0 \mathrm{~mm})$ contains numerous inclusions of apatite and zircon.

According to the chemical and isotope composition (A/ CNK: $0.81-1.01 ; \mathrm{SiO}_{2}: 62.2-68.3$ wt. $\%, \mathrm{Al}_{2} \mathrm{O}_{3}: 14.9-15.5$ wt. $\%, \mathrm{~K}_{2} \mathrm{O}: 4.1-5.0$ wt. $\%, \mathrm{Na}_{2} \mathrm{O}: 2.5-3.6$ wt. $\% ; \mathrm{Fe}_{2} \mathrm{O}_{3} /$ FeO: $0.20-0.36,{ }^{87} \mathrm{Sr}^{86}{ }^{86} \mathrm{Sr}_{350 \mathrm{Ma}}: 0.707-0.709, \varepsilon_{\mathrm{Nd}}{ }^{350 \mathrm{Ma}}:-3.3$ to -4.5; Zachariáś 1998) the granodiorite can be classified as I-type. It belongs to the high-K calc-alkaline group of the CBPC in the sense of Holub et al. (1997).

Biotite hornfels represents the most common country rock. It is dark and massive or laminated. The mineral proportions are highly variable: plagioclase (45-30\%; $\left.\mathrm{An}_{20-35}\right)$, biotite (40-20\%), and quartz (50-5\%). Ac- cessories are represented by titanite (rarely up to $20 \%$ ), zircon and sulphides.

Quartzite and feldspathic quartzite are less common than biotite hornfels. Greyish quartzite typically contains more than $80 \%$ of quartz, while the quartz content in greenish feldspathic quartzite is only $50-70 \%$. Other major minerals in the latter rock type are represented by plagioclase (up to $30 \% ; \mathrm{An}_{0-25}$ ), biotite (up to $10 \%$ ) and K-feldspar (up to $10 \%$ ).

\subsection{Classification of hydrothermal alteration products}

Four principal types of hydrothermal alterations were distinguished in the PH deposit. They all preceded or accompanied formation of gold-bearing quartz veins and occur either in the granodiorite or in its closest vicinity. Hydrothermal products can be classified, based on mineral paragenesis, relative age relationships, and stress orientation during their formation, into early, main and late products (Fig. 3).

$K$-alteration- $l$ is demonstrated by widespread selectively pervasive microscopic replacement of magmatic plagioclase of the granodiorite by K-feldspar along microfractures or grain boundaries, and formation of fine-grained biotite-2 (isolated aggregates or overgrowths on the magmatic biotite-1 phenocrysts). Rare diffuse schlieren (with up to 11 wt. $\% \mathrm{~K}_{2} \mathrm{O}$ ) of reddish to pinkish microcline masses (with rare quartz and hornblende anhedral grains) in the granodiorite porphyries can probably also be assigned to the K-alteration- 1 .

$K$-alteration-2 is fracture-related and resulted in formation of microcline-dominated veinlets (up to $50 \mathrm{~mm}$ thick) and microcline-dominated envelopes (rims) of the earliest quartz veins $\left(\mathrm{Q}_{1}\right.$; Fig. $\left.2 \mathrm{~g}\right)$. Microcline is commonly accompanied by hornblende, and minor scheelite, titanite and zircon (Fig. 2f). Well crystallized euhedral amphibole, titanite and zircon were also found enclosed in $\mathrm{Q}_{1}$ gangue. Because they are several times larger than the same phases of magmatic origin (in PH granitoids), their hydrothermal nature is unambiguous. Fractures with K-alteration-2 occur in the central part of the granodiorite stock only.

Silicification-1 is manifested by inhomogeneous bleaching of contact hornfels in close proximity to the $\mathrm{PH}$ granodiorite stock. The bleached zones exhibit both sharp and diffuse contacts. Removal of the biotite ( \pm hornblende), decrease in the plagioclase grain size and increase in the anorthite component from $\mathrm{An}_{26-32}$ to $\mathrm{An}_{32-38}$ were observed. Silicified-1 metasediments are frequently crosscut by monomineral hornblende-1 veinlets $(\leq 2 \mathrm{~mm}$ thick). Au-bearing quartz veins $\left(\mathrm{Q}_{2}\right.$ through $\left.\mathrm{Q}_{4}\right)$ crosscut both hornblende-1 veinlets and silicified-1 zones.

Silicification-2 represents fracture-related alteration (Fig. 2h). It is developed only in metasediments and 

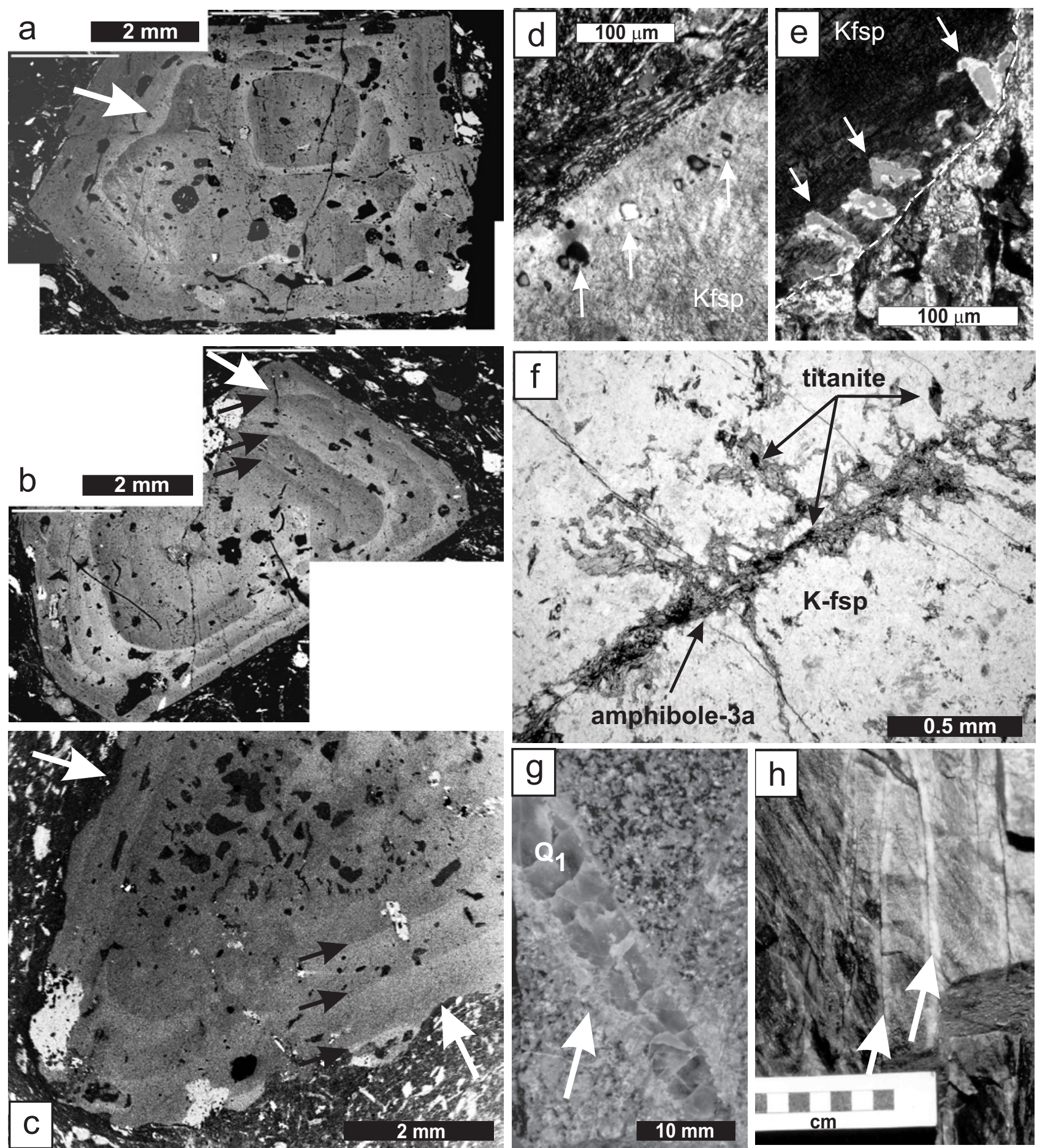

Fig. 2 a-c) Back-scattered electron images of K-feldspar phenocrysts from a granodiorite porphyry dyke. Dark anhedral inclusions correspond to quartz, grey to biotite, hornblende and plagioclase. Lighter (white) colours of the K-feldspar correspond to higher contents of the barium admixture. Black arrows mark individual growth zones, white arrows resorption textures. Individual growth zones typically start with the most Ba-rich composition. a - Phenocryst with partially resorbed core. $\mathbf{b}-$ Phenocryst with undisturbed older crystallization growth zones. $\mathbf{c}-$ Phenocryst with partial resorption of the outermost growth zone. d-f) Photomicrographs of K-feldspar phenocryst rims from granodiorite (crossed nicols). d - Outer rim of K-feldspar phenocryst with a line of quasi-circular quartz inclusions (arrows; crossed nicols). e - Outer rim of K-feldspar phenocryst with a zone of quartz-feldspar graphic intergrowths (arrows; crossed nicols). f - Microfracture associated with K-alteration-2 filled with amphibole-3a and titanite and rimmed by K-feldspar (not indicated on the photomicrograph; crossed nicols). g-h) Field photographs of hydrothermally altered rocks. $\mathbf{g}$ - Early quartz vein $\left(\mathrm{Q}_{1}\right)$ with an envelope of K-feldspar (arrow; K-alteration-2). $\mathbf{h}$ - Fracture-related silicification (arrows) in hornfels. 


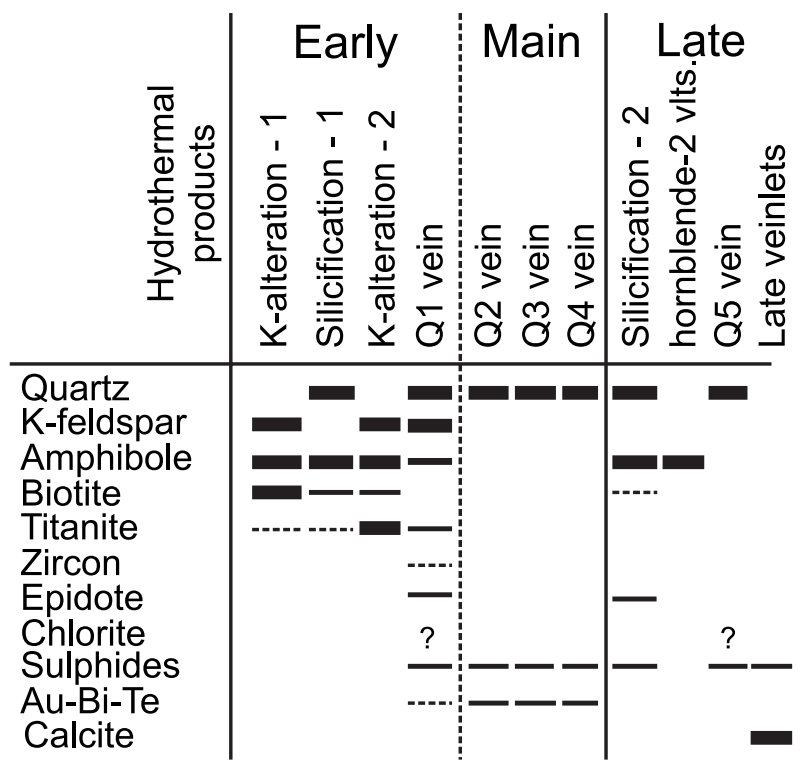

structurally restricted to low-angle reverse faults/joints. There are several $\mathrm{mm}$ thick zones of intensive bleaching, where nearly all the mafic minerals (biotite, hornblende) are removed. Plagioclase is subjected to a decrease in grain size, formation of a "sieve texture" and to a small change in composition $\left(\mathrm{An}_{24-18} \rightarrow \mathrm{An}_{17-14}\right)$. Low-angle reverse faults/joints are locally filled by hornblende ( \pm quartz, albite) paragenesis (referred to as hornblende-2 veinlets). Formation of silicification- 2 and of associated hornblende-2 veinlets most probably only briefly preceded the formation of late quartz veins $\left(\mathrm{Q}_{5}\right)$, which are exclusively hosted by the same structures.

Based on Gresens (1968) and Grant (1986) type of calculations (Zachariáš 1998), silicification (-1 and -2) is associated with gain of $\mathrm{SiO}_{2}\left(15\right.$ to 50 rel. \%) and $\mathrm{Na}_{2} \mathrm{O}$ (30 to 15 rel. \%) and loss of most of other elements (up to $c .-50$ rel. $\%$ ).

Fig. 3 Simplified paragenetic scheme of hydrothermal products distinguished in the Petráčkova hora gold deposit.

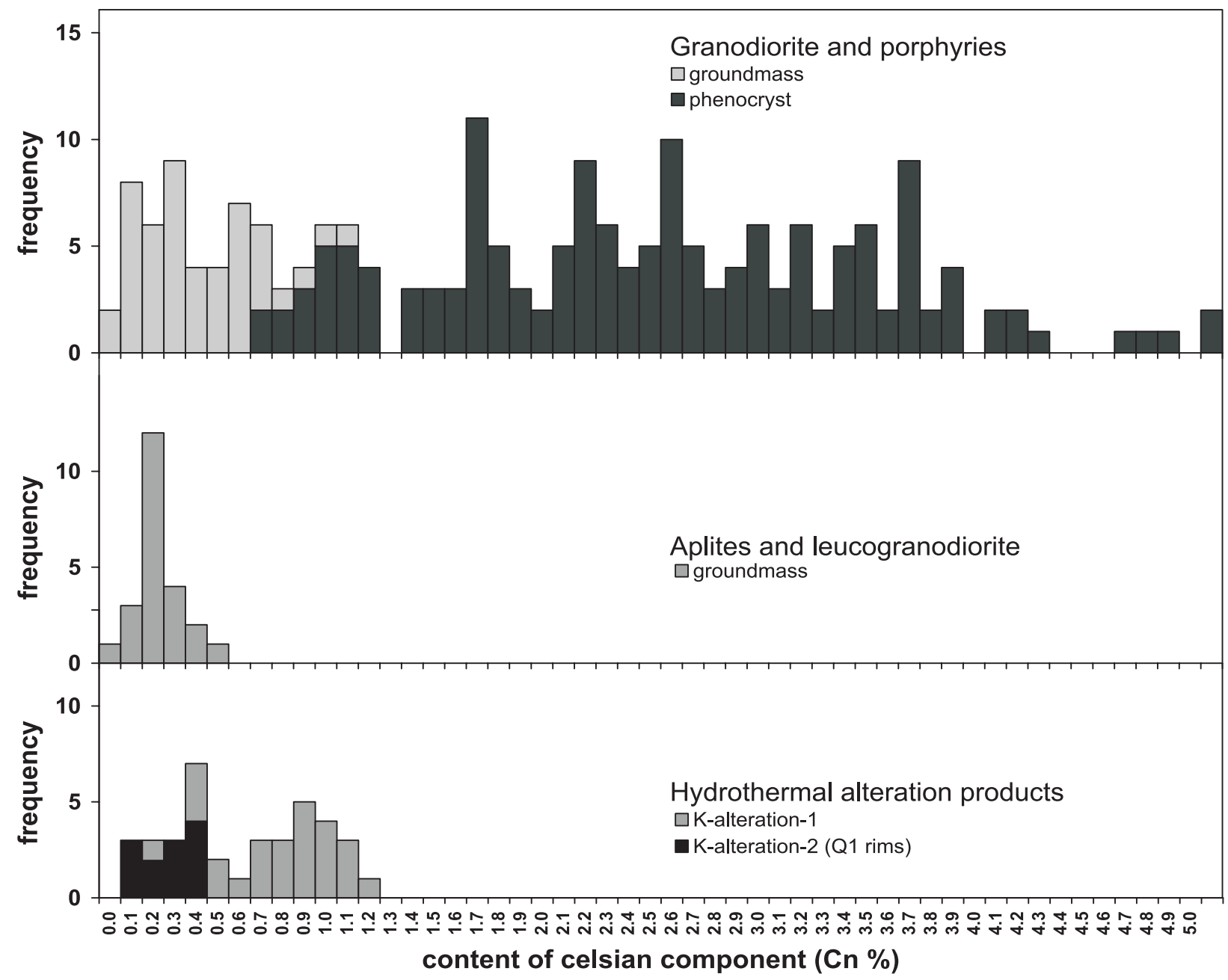

Fig. 4 Histograms of the celsian $\left(\mathrm{BaAl}_{2} \mathrm{Si}_{2} \mathrm{O}_{8} ; \mathrm{Cn}\right)$ content distribution in $\mathrm{K}$-feldspar. The data are grouped in three sets: older intrusive phases (granodiorite and porphyries), young intrusive dykes (aplites and leucogranodiorite) and products of hydrothermal alterations. 


\subsection{Mineral chemistry}

\subsubsection{K-feldspar}

In order to characterize magmatic to hydrothermal evolution, the following K-feldspars were distinguished: phenocrysts vs. groundmass (in intrusives) and hydrothermal alteration products (groundmass associated with fracture- and vein-related alterations). In all cases, the only significant difference in chemistry was noticed in the barium content [up to $2.60 \mathrm{wt} \% \mathrm{BaO}$, i.e. $4.86 \%$ of the celsian ( $\mathrm{Cn} ; \mathrm{BaAl}_{2} \mathrm{Si}_{2} \mathrm{O}_{8}$ ) component] (Tab. 1). The following trends were observed:

i) in a single granitoid sample, the K-feldspar phenocrysts always exhibit higher $\mathrm{Cn}$ content $(5-1 \% \mathrm{Cn}$;
Fig. 4) than grains of the groundmass $(0.8-0.2 \% \mathrm{Cn})$; ii) within single phenocryst, the barium content decreases from the core $(5-2 \% \mathrm{Cn})$ to the $\operatorname{rim}(\sim 1 \% \mathrm{Cn})$, either in an oscillatory (more frequently; Fig. 5) or in a continuous manner; iii) no significant differences in the $\mathrm{Cn}$ content and in core to rim profiles were found between the granodiorite and granodiorite porphyries; iv) the K-feldspar of the equigranular late magmatic differentiates (aplite, leucocratic granodiorite and granodiorite dike) exhibits lower $\mathrm{Cn}$ content $(0.6-0.0 \% \mathrm{Cn})$ than the groundmass feldspar of the host granodiorite; v) in hydrothermal products (K-alteration-1, -2 ), the $\mathrm{Cn}$ content is rather variable $(1.3-0.1 \% \mathrm{Cn})$, but the $\mathrm{K}$-alteration-2 related feldspars tend to have lower $\mathrm{Ba}$ content than feldspars related to the K-alteration-1 (Fig. 4).

Tab. 1 Representative analyses of K-feldspar (wt. \% and recalculated on the basis of $8 \mathrm{O}$ )

\begin{tabular}{|c|c|c|c|c|c|c|c|c|c|}
\hline Sample: & 77 & $328-5$ & $328-50$ & $21-28$ & 194-7 & $201-34$ & $328-17$ & $185-30$ & $294-26$ \\
\hline \multirow[t]{2}{*}{ Rock type* } & GD cen & GD cen & GD cen & $\begin{array}{c}\text { LeGD } \\
\text { (GDcen) }\end{array}$ & $\begin{array}{c}\text { Aplite } \\
\text { (GDper) }\end{array}$ & GD cen & GD cen & $\begin{array}{l}\text { Q1 vein } \\
\text { (MB) }\end{array}$ & $\begin{array}{l}\text { Q1 vein } \\
\text { (GDcen) }\end{array}$ \\
\hline & $\mathrm{P}$ & $\mathrm{P}$ & $\mathrm{M}$ & $\mathrm{M}$ & M & K-alt-2 & K-alt-1 & K-alt-2 & K-alt-2 \\
\hline $\mathrm{SiO}_{2}$ & 62.87 & 62.68 & 64.63 & 63.45 & 64.44 & 64.08 & 64.71 & 63.68 & 63.91 \\
\hline $\mathrm{TiO}_{2}$ & 0.05 & 0.02 & 0.00 & 0.00 & 0.00 & 0.00 & 0.00 & 0.00 & 0.03 \\
\hline $\mathrm{Al}_{2} \mathrm{O}_{3}$ & 19.24 & 20.20 & 20.07 & 18.59 & 18.56 & 19.35 & 18.97 & 19.92 & 18.66 \\
\hline $\mathrm{Cr}_{2} \mathrm{O}_{3}$ & 0.00 & 0.00 & 0.02 & 0.00 & 0.00 & 0.00 & 0.00 & 0.00 & 0.00 \\
\hline $\mathrm{FeO}$ & 0.00 & 0.00 & 0.00 & 0.00 & 0.08 & 0.00 & 0.00 & 0.00 & 0.00 \\
\hline $\mathrm{MnO}$ & 0.00 & 0.03 & 0.00 & 0.03 & 0.00 & 0.00 & 0.00 & 0.00 & 0.00 \\
\hline $\mathrm{MgO}$ & 0.00 & 0.02 & 0.00 & 0.00 & 0.00 & 0.00 & 0.00 & 0.04 & 0.00 \\
\hline $\mathrm{CaO}$ & 0.00 & 0.00 & 0.00 & 0.00 & 0.00 & 0.00 & 0.00 & 0.00 & 0.00 \\
\hline $\mathrm{BaO}$ & 2.60 & 1.45 & 0.23 & 0.12 & 0.08 & 0.13 & 0.36 & 0.37 & 0.05 \\
\hline $\mathrm{Na}_{2} \mathrm{O}$ & 0.79 & 0.39 & 0.51 & 0.59 & 0.51 & 0.37 & 0.97 & 0.68 & 0.85 \\
\hline $\mathrm{K}_{2} \mathrm{O}$ & 14.42 & 15.70 & 14.17 & 16.47 & 15.62 & 16.27 & 14.59 & 15.31 & 15.93 \\
\hline Total: & 99.97 & 100.49 & 99.63 & 99.25 & 99.29 & 100.20 & 99.60 & 100.00 & 99.43 \\
\hline $\mathrm{Si}^{+4}$ & 2.94 & 2.91 & 2.96 & 2.97 & 2.99 & 2.96 & 2.99 & 2.94 & 2.98 \\
\hline $\mathrm{Ti}^{+4}$ & 0.00 & 0.00 & 0.00 & 0.00 & 0.00 & 0.00 & 0.00 & 0.00 & 0.00 \\
\hline $\mathrm{Al}^{+3}$ & 1.06 & 1.11 & 1.09 & 1.03 & 1.02 & 1.05 & 1.03 & 1.08 & 1.02 \\
\hline $\mathrm{Cr}^{+3}$ & 0.00 & 0.00 & 0.00 & 0.00 & 0.00 & 0.00 & 0.00 & 0.00 & 0.00 \\
\hline $\mathrm{Fe}^{+2}$ & 0.00 & 0.00 & 0.00 & 0.00 & 0.00 & 0.00 & 0.00 & 0.00 & 0.00 \\
\hline $\mathrm{Mn}^{+2}$ & 0.00 & 0.00 & 0.00 & 0.00 & 0.00 & 0.00 & 0.00 & 0.00 & 0.00 \\
\hline $\mathrm{Mg}$ & 0.00 & 0.00 & 0.00 & 0.00 & 0.00 & 0.00 & 0.00 & 0.00 & 0.00 \\
\hline $\mathrm{Ca}$ & 0.00 & 0.00 & 0.00 & 0.00 & 0.00 & 0.00 & 0.00 & 0.00 & 0.00 \\
\hline $\mathrm{Ba}$ & 0.05 & 0.03 & 0.00 & 0.00 & 0.00 & 0.00 & 0.01 & 0.01 & 0.00 \\
\hline $\mathrm{Na}$ & 0.07 & 0.04 & 0.05 & 0.05 & 0.05 & 0.03 & 0.09 & 0.06 & 0.08 \\
\hline $\mathrm{K}$ & 0.86 & 0.93 & 0.83 & 0.98 & 0.93 & 0.96 & 0.86 & 0.90 & 0.95 \\
\hline Sum & 4.99 & 5.02 & 4.93 & 5.04 & 4.98 & 5.01 & 4.97 & 5.00 & 5.02 \\
\hline An & 0.00 & 0.00 & 0.00 & 0.00 & 0.00 & 0.00 & 0.00 & 0.00 & 0.00 \\
\hline Or & 87.82 & 93.80 & 94.37 & 94.64 & 95.13 & 96.43 & 90.20 & 93.03 & 92.42 \\
\hline $\mathrm{Ab}$ & 7.31 & 3.54 & 5.16 & 5.15 & 4.72 & 3.33 & 9.11 & 6.28 & 7,49 \\
\hline $\mathrm{Cn}$ & 4.86 & 2.66 & 0.47 & 0.21 & 0.15 & 0.24 & 0.68 & 0.69 & 0.09 \\
\hline
\end{tabular}

*Explanations: GD cen = granodiorite central, GD per = granodiorite peripheral, LeGD = leucogranodiorite dyke hosted by central granodiorite, Aplite $=$ aplite dyke hosted by peripheral granodiorite, $\mathrm{MB}=$ metabasite, $\mathrm{Q} 1$ vein $=\mathrm{K}$-feldspar alteration rim around the $\mathrm{Q}_{1}$ quartz vein, $\mathrm{P}=$ magmatic phenocryst, $\mathrm{M}=$ magmatic groundmass, $\mathrm{K}$-alt-1 = K-alteration-1, K-alt-2 = K-alteration-2

$\mathrm{An}=$ anorthite, $\mathrm{Or}=$ orthoclase, $\mathrm{Ab}=$ albite, $\mathrm{Cn}=$ celsian $(\mathrm{mol} . \%)$ 

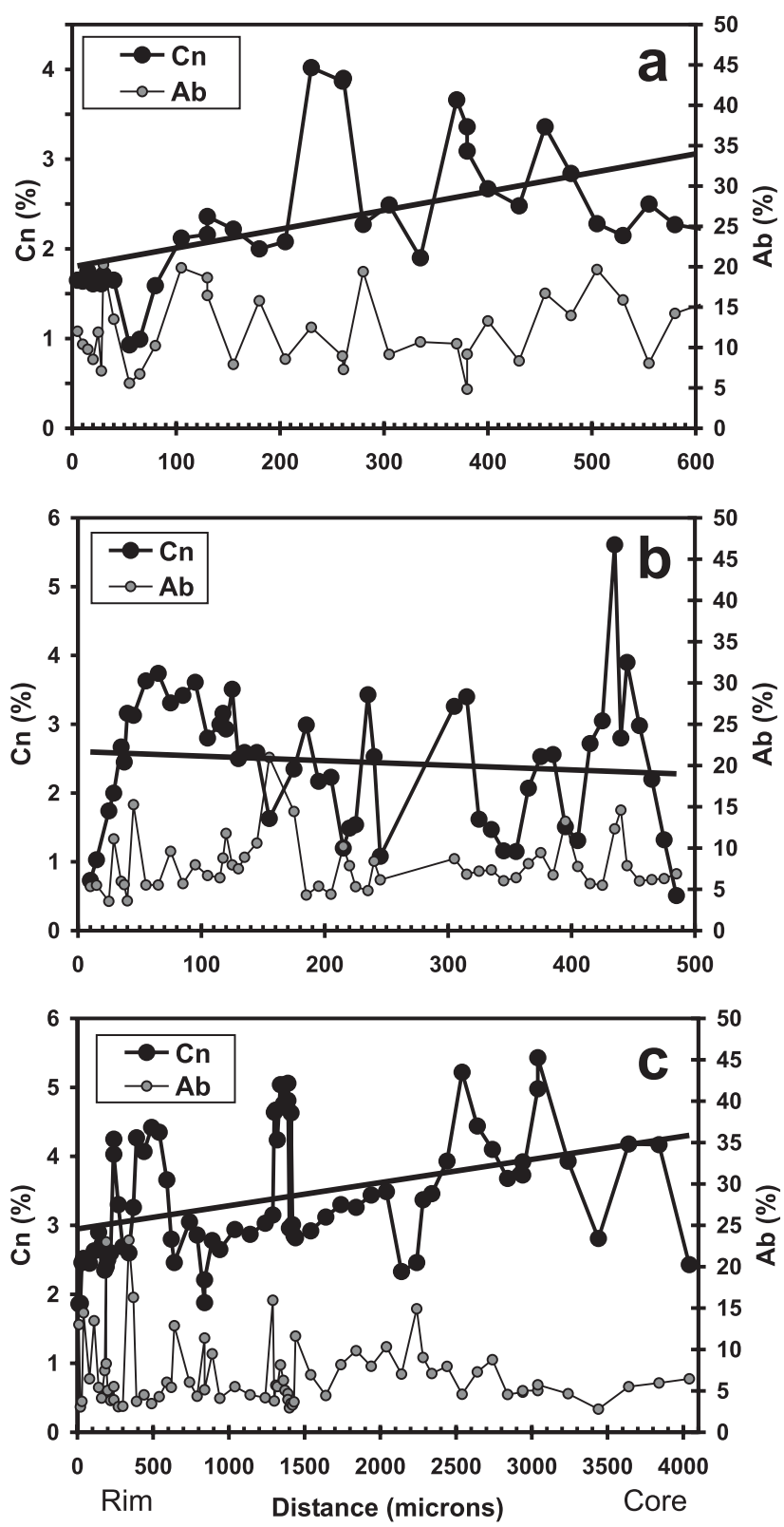

Fig. 5 Compositional rim to core profiles (WDS system) across selected $\mathrm{K}$-feldspar phenocrysts. Because the calcium content was almost always below the detection limit, only celsian $(\mathrm{Cn})$ and albite $(\mathrm{Ab})$ components are shown. Thick line represents linear regression of celsian data. $\mathbf{a}$ - Petráčkova Hora granodiorite porphyry sample. b - Petráčkova Hora granodiorite sample. $\mathbf{c}$ - Trepanda granodiorite porphyry sample.

\subsubsection{Biotite}

Three types of biotite were distinguished: i) biotite-1 is of magmatic origin and has the form of flakes up to $1 \mathrm{~mm}$ across and free of recrystallization. It forms microphenocrysts in the porphyries and/or groundmass in the granodiorite. When the former are ductile-deformed, flakes of biotite-1 are transformed into mica-fish type porphyroclasts; ii) biotite-2: small homogeneous flakes
$(0.1-0.3 \mathrm{~mm})$ or aggregates of fine-grained biotite ("shred-like biotite"; c. $0.02 \mathrm{~mm}$ ). Biotite-2 is either disseminated in the granodiorite or rims biotite- 1 and/or amphibole-1 phenocrysts. When the rock was subjected to ductile deformation, biotite-2 grew syntectonically in foliation planes, or in the pressure shadows of biotite- 1 and amphibole- 1 porphyroclasts. The nature of biotite- 2 is more difficult to assess. In deformed porphyries, it can be considered to be metamorphic, while it is deuteric in the weakly deformed granodiorite (hydrothermal origin is also possible); iii) biotite-3 is of hydrothermal origin and includes fine-grained biotite from the zones richest in $\mathrm{K}_{2} \mathrm{O}$ (i.e. altered) in granodiorite or in porphyries. All the biotites of this generation (irrespective of their shape and size) form fracture- and vein-related $\mathrm{K}$-alterations hosted by the $\mathrm{PH}$ granodiorite.

Discrimination between biotite-1, -2 and -3 is impossible on the basis of chemical analyses only. All the three groups significantly overlap in all their crystallochemical parameters (Fig. 6, Tab. 2). In general, the titanium content decreases in the sequence biotite- $1 \rightarrow$ biotite- 2 $\rightarrow$ biotite-3. Biotite- 2 is often depleted in potassium. This can be attributed either to the presence of biotite with disturbed structure facilitating potassium loss during microprobe analysis, or to a presence of intimate intergrowths of biotite-2 and clay/chlorite minerals indistinguishable in the BSE images, even at high magnifications. Well-crystallized hydrothermal biotite-3 has again normal potassium contents.

\subsubsection{Amphibole}

Similar to biotite, three types of amphibole were distinguished: primary magmatic (amphibole-1), metamorphic/ deuteric (amphibole-2) and hydrothermal (amphibole-3). The hydrothermal amphiboles can be further subdivided into early (-3a; K-alterations, silicification-1 and hornblende- 1 veinlets) and late (-3b; silicification-2, hornblende-2 veinlets) subgroups.

The analysed amphiboles correspond largely to magnesiohornblende or actinolite (Fig. 7, Tab. 3). The Mg number (MG\#) varies from 39 to 77 if all the iron is considered to be $\mathrm{Fe}^{2+}$, or between 48 and 94 when recalculation to $\mathrm{Fe}^{2+}$ and $\mathrm{Fe}^{3+}$ is employed. In both calculations, however, most of the analyses have a MG\# value higher than 50.

No significant compositional differences were found either between amphibole-1 in granodiorite and in porphyries, or between amphibole- 2 and amphibole- 1 occurring in the same host rock. Early hydrothermal amphiboles (-3a) are almost compositionally identical to those of magmatic origin (amphibole-1). The late-hydrothermal amphiboles $(-3 b)$ fall partly off the trend for the PH magmatic amphibole. While the MG\# values decrease 

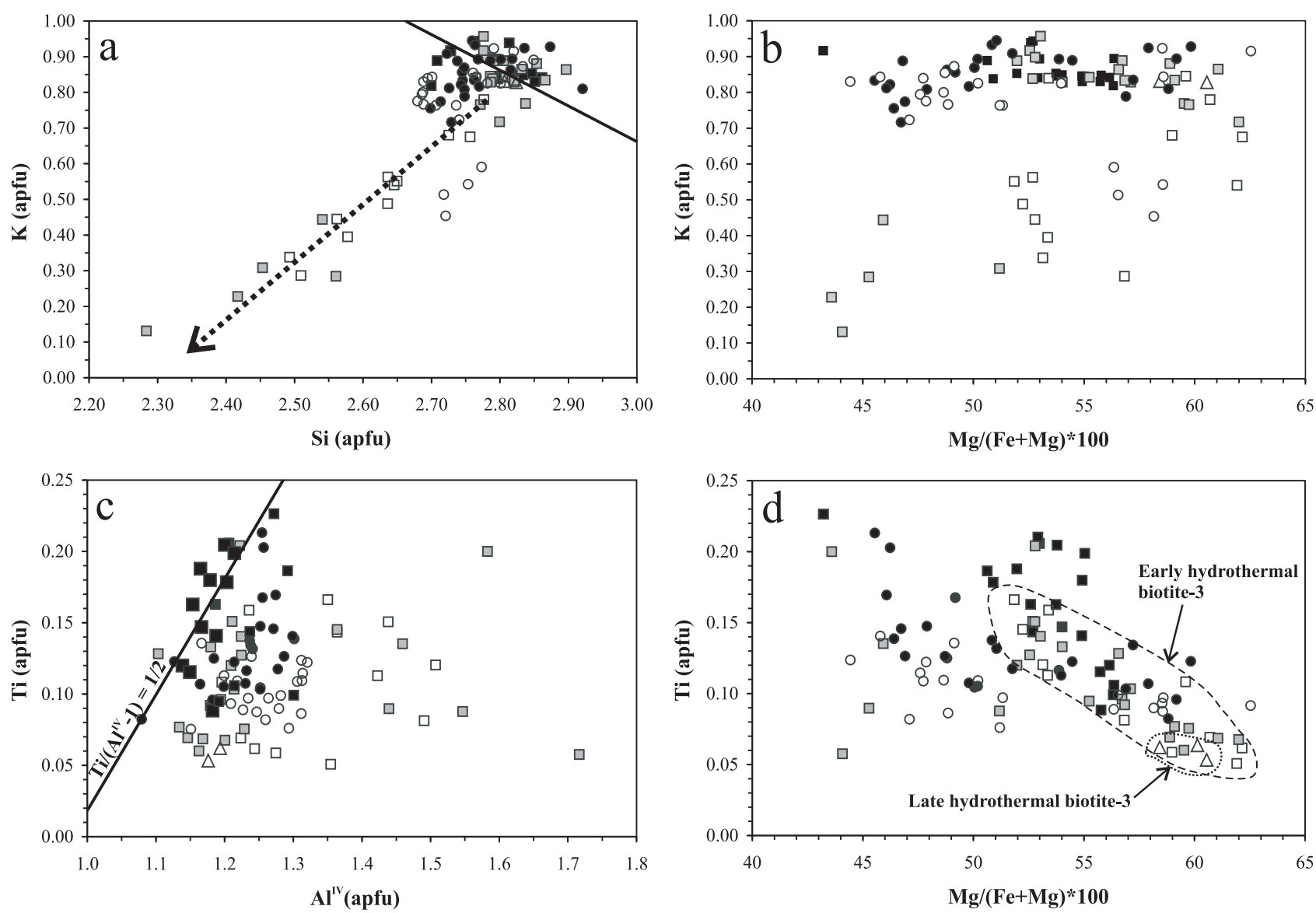

Granodiorite:

- magmatic biotite (biotite-1)

口 recrystallized biotite (biotite-2)

$\square \quad$ alteration biotite (biotite-3; disseminated, fine-grained)

$\Delta$ alteration biotite (biotite-3, fracture-related, fine-grained)

Granodiorite porphyries:

- magmatic biotite (biotite-1)

- recrystallized biotite (biotite-2)

Fig. 6 Compositional variations in biotite of magmatic (biotite-1), metamorphic/deuteric (biotite-2) and hydrothermal alteration (biotite-3) origins. $\mathbf{a}-\mathbf{b}$ - Deficit of potassium in some fine-grained biotites may be caused by late hydrothermal overprint. The dotted arrow indicates the effect of hypothetical biotite-clay intergrowths/alteration. $\mathbf{c}-$ Correlation of $\mathrm{Ti}$ and $\mathrm{Al}^{\mathrm{IV}}$ in analysed biotites. $\mathbf{d}-\mathrm{Correlation}$ of $\mathrm{Ti}$ and $\mathrm{Mg} /\left(\mathrm{Mg}+\mathrm{Fe}{ }^{2+}\right)$ in analysed biotites. The late hydrothermal biotites are the most Mg-rich and Ti-poor.

from core to rim in the late hydrothermal hornblende $(-3 b)$, they remain constant, or increase slightly, in the early hydrothermal amphiboles (-3a and 2).

\section{Discussion}

\subsection{Magmatic vs metasomatic origin of K-feldspar phenocrysts}

Based on the presence of numerous inclusions of silicate minerals, Drozen et al. (1986) advocated the metasomatic origin of K-feldspar phenocrysts in his dacites and dacitic tuffs (both referred to as granodiorite or granodiorite porphyries in this work). According to the present author, the K-feldspar phenocrysts in all types of granitoid rocks found within the RTB area are of purely magmatic origin. This is supported by: i) the absence of K-feldspar porphyroblasts in metasedimentary country rocks in the vicinity of porphyritic granitoids; ii) the gradually decreasing contents of the celsian component from phenocrysts to groundmass, observed systematically in all the $\mathrm{PH} / \mathrm{RTB}$ granitoids; iii) the presence of undisturbed oscillatory Bazoning (Fig. 5) in phenocrysts of the $\mathrm{PH}$ granodiorite and porphyries (similar textures are absent in hydrothermal or metamorphic K-feldspars).

In some RTB granodiorite porphyries, partially resorbed cores (Fig. 2a) or rims (Figs. 2b-c) were found in $\mathrm{K}$-feldspar phenocrysts indicating discontinuous feldspar crystallization and unspecified changes in the pressure/temperature and/or chemistry of the parental magma. 
Tab. 2 Representative analyses of biotite (wt. \% and recalculated on the basis of $11 \mathrm{O}+\mathrm{OH}$ )

\begin{tabular}{|c|c|c|c|c|c|c|c|c|c|}
\hline Sample: & 294 & 294 & 194 & 194 & $210 \mathrm{C}$ & $210 \mathrm{C}$ & $211 \mathrm{G}$ & 201 & 201 \\
\hline Rock & GD cen & GD cen & GD per & GD per & GD cen & GD cen & GD cen & GD cen & GD cen \\
\hline biotite* & PM & PM & PM & PM & PM & Sil-1 & Kalt-1 & Kalt-2 & Kalt-2 \\
\hline $\mathrm{SiO}_{2}$ & 37.28 & 35.85 & 37.06 & 37.17 & 38.07 & 37.56 & 33.21 & 37.28 & 38.35 \\
\hline $\mathrm{TiO}_{2}$ & 2.87 & 2.41 & 2.12 & 3.63 & 1.23 & 3.68 & 2.35 & 1.11 & 1.97 \\
\hline $\mathrm{Al}_{2} \mathrm{O}_{3}$ & 14.88 & 15.07 & 15.20 & 15.02 & 14.29 & 14.62 & 19.37 & 16.21 & 15.74 \\
\hline $\mathrm{Cr}_{2} \mathrm{O}_{3}$ & 0.01 & 0.04 & 0.07 & 0.01 & 0.28 & 0.16 & 0.01 & 0.01 & n.a. \\
\hline $\mathrm{FeO}$ & 19.30 & 18.77 & 20.39 & 19.37 & 18.20 & 19.59 & 23.40 & 17.64 & 17.81 \\
\hline $\mathrm{MnO}$ & 0.24 & 0.20 & 0.15 & 0.14 & 0.12 & 0.20 & 0.24 & 0.13 & 0.15 \\
\hline $\mathrm{MgO}$ & 12.01 & 11.89 & 12.38 & 12.15 & 14.62 & 12.39 & 11.15 & 16.25 & 14.74 \\
\hline $\mathrm{BaO}$ & 0.23 & 0.34 & 0.46 & 0.12 & n.a. & 0.16 & 0.10 & n.a. & 0.22 \\
\hline $\mathrm{CaO}$ & n.a. & n.a. & n.a. & n.a. & n.a. & 0.03 & 0.15 & 0.05 & 0.03 \\
\hline $\mathrm{Na}_{2} \mathrm{O}$ & 0.01 & 0.15 & 0.11 & 0.34 & 0.18 & 0.08 & 0.08 & 0.18 & 0.06 \\
\hline $\mathrm{K}_{2} \mathrm{O}$ & 9.75 & 9.69 & 9.25 & 9.42 & 9.21 & 9.42 & 4.55 & 7.16 & 9.06 \\
\hline Total: & 96.58 & 94.41 & 97.19 & 97.37 & 96.20 & 97.89 & 94.61 & 96.02 & 98.13 \\
\hline $\mathrm{Si}^{\mathrm{IV}}$ & 5.63 & 5.55 & 5.58 & 5.56 & 5.71 & 5.59 & 5.08 & 5.51 & 5.61 \\
\hline $\mathrm{Al}^{\mathrm{IV}}$ & 2.37 & 2.45 & 2.42 & 2.44 & 2.29 & 2.41 & 2.92 & 2.49 & 2.39 \\
\hline Sum T & 8.00 & 8.00 & 8.00 & 8.00 & 8.00 & 8.00 & 8.00 & 8.00 & 8.00 \\
\hline$\overline{\mathrm{Al}} 1^{\mathrm{VI}}$ & 0.27 & 0.30 & 0.28 & 0.20 & 0.23 & 0.15 & 0.57 & 0.34 & 0.32 \\
\hline $\mathrm{Ti}^{\mathrm{VI}}$ & 0.33 & 0.28 & 0.24 & 0.41 & 0.14 & 0.41 & 0.27 & 0.12 & 0.22 \\
\hline $\mathrm{Cr}$ & 0.00 & 0.00 & 0.01 & 0.00 & 0.03 & 0.02 & 0.00 & 0.00 & \\
\hline $\mathrm{Fe}^{+2}$ & 2.44 & 2.43 & 2.57 & 2.42 & 2.28 & 2.44 & 2.99 & 2.18 & 2.18 \\
\hline $\mathrm{Mn}^{+2}$ & 0.03 & 0.03 & 0.02 & 0.02 & 0.02 & 0.03 & 0.03 & 0.02 & 0.02 \\
\hline $\mathrm{Mg}$ & 2.70 & 2.74 & 2.78 & 2.71 & 3.27 & 2.75 & 2.54 & 3.58 & 3.21 \\
\hline Sum O & 5.77 & 5.79 & 5.89 & 5.76 & 5.97 & 5.79 & 6.41 & 6.24 & 5.95 \\
\hline $\mathrm{Ba}$ & 0.01 & 0.02 & 0.03 & 0.01 & & 0.01 & 0.01 & & 0.01 \\
\hline $\mathrm{Ca}$ & & & & & & & 0.02 & 0.01 & \\
\hline $\mathrm{Na}$ & 0.00 & 0.05 & 0.03 & 0.10 & 0.05 & 0.02 & 0.02 & 0.05 & 0.02 \\
\hline $\mathrm{K}$ & 1.88 & 1.91 & 1.78 & 1.80 & 1.76 & 1.79 & 0.89 & 1.35 & 1.69 \\
\hline Sum A & 1.89 & 1.98 & 1.84 & 1.90 & 1.81 & 1.82 & 0.94 & 1.41 & 1.72 \\
\hline MG\# & 52.59 & 53.03 & 51.98 & 52.79 & 58.88 & 52.99 & 45.93 & 62.15 & 59.60 \\
\hline
\end{tabular}

"Explanations: GD cen = granodiorite central; GD per = granodiorite peripheral; PM = primary magmatic; Sil-1 = silicification-1; Kalt-1 = K-alteration-1; Kalt-2 $=$ K-alteration-2; $\mathrm{MG} \#=100 \mathrm{Mg} /\left(\mathrm{Mg}+\mathrm{Fe}_{\mathrm{tot}}{ }^{2+}\right) ;$

Sum $\mathrm{T}=$ tetrahedral site sum, Sum $\mathrm{O}=$ octahedral site sum, Sum $\mathrm{A}=\mathrm{A}$ site sum

\subsection{General comments on the barium con- tent in K-feldspar}

There was observed an overall trend of decreasing average barium content in K-feldspar. The highest is in the $\mathrm{K}$-feldspar phenocrysts (average: $2.55 \% \mathrm{Cn}$ ), lower in the granodiorite groundmass (average: $0.50 \% \mathrm{Cn}$ ) and the lowest in the groundmass of aplite/leucogranodiorite (both younger than granodiorite). This variation can be best explained as an effect of magmatic fractional crystallization during which barium would be accommodated in the structure of K-feldspar and biotite phenocrysts and depleted in the residual melt. During normal magmatic crystallization not disturbed by the magma mixing processes, the cores of the K-feldspar phenocrysts are typically the most Ba-rich, their rims less so and the groundmass K-feldspar relatively Ba-poor (e.g. reviews of Smith 1974 and Vernon 1986).
We can suggest similar behaviour of barium in hydrothermal processes. However, due to lower temperatures, more subtle changes/differences in the Ba concentrations in various alteration products can be expected. Surprisingly, the range of Ba contents in early hydrothermal feldspars (K-alteration-1; average: $0.90 \%$ Cn; Fig. 4) is similar to that of the granodiorite groundmass, but higher than that of the aplite/leucogranodiorite groundmass (although these preceded formation of Kalteration-1).

Due to the large difference in average atomic number between the orthoclase and the celsian, internal K-feldspar phenocryst/grain growth/resorption textures can be successfully studied in the BSE mode when highlighted by differences in the Ba content (e.g. Stimac and Pearce 1992, Anderson et al. 2000). The very low rate of Ba diffusion (Cherniak 2002) in K-feldspar (sanidine) favours preservation of the primary magmatic Ba-growth zoning 

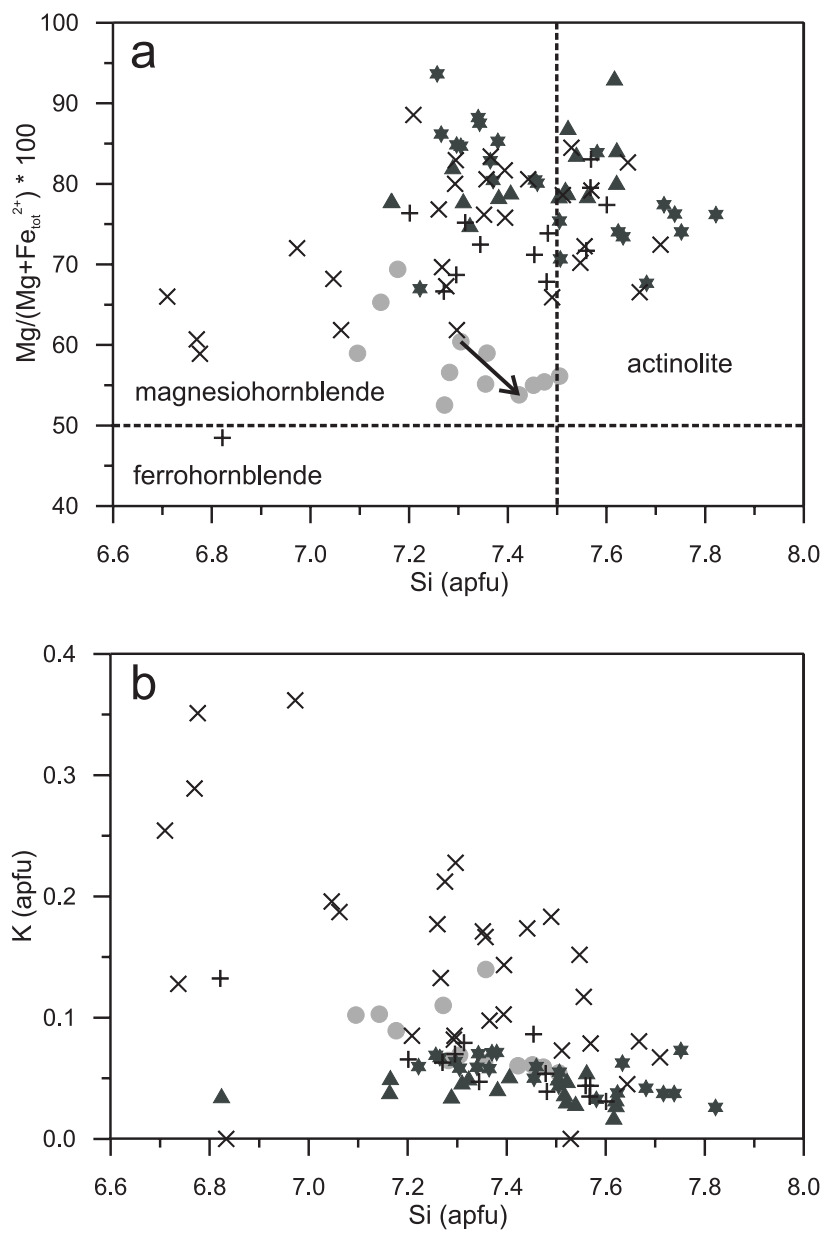

+ magmatic primary (amphibole-1)

$\times$ metamorphic/deuteric (amphibole-2)

* early hydrothermal (K-alterations; amphibole-3a)

- early hydrothermal (hornblende-1 veinlets; amphibole-3a)

- late hydrothermal (hornblende-2 veinlets; amphibole-3b)

Fig. 7 Composition and classification (Leake et al. 1997) of hornblende of various origins. Arrow designates the core to rim evolution trend.

in K-feldspar phenocrysts, even when younger hydrothermal processes affected the rock.

Resorption textures, such as irregular and compositionally distinct grain cores, truncation of individual growth zones and surface erosion embayments indicate unequivocally physical (temperature/pressure) and/or chemical disequilibria between the K-feldspar phenocryst and the magma (e.g. Stimac and Pearce 1992). These textures can be associated with intrusion of a new and less differentiated melt (i.e. magma mixing; e.g. Gagnevin et al. 2005), or with gravitational sinking of K-feldspar phenocrysts into deeper, and less differentiated, parts of the same magma chamber (e.g. Anderson et al. 2000). In any case, the new and less differentiated magma is likely to be richer in $\mathrm{Ba}$ than was the magma from which either the whole phenocryst, or at least its youngest growth zones (i.e. those preceding the onset of resorption) started to grow. Consequently, the first K-feldspar zone to overgrow the partially resorbed phenocryst would be rich in $\mathrm{Ba}$. The following growth zones (rimward) are again usually increasingly depleted in $\mathrm{Ba}$ due to the ongoing $\mathrm{K}$-feldspar fractional crystallization. Multiple resorption textures coupled with Ba-enrichment in the overgrowths thus seem to indicate multiple/repetitive magma mixing processes.

Stimac and Pearce (1992) gave an alternative explanation for the formation of Ba-enriched zones associated with the resorption surfaces. They suggested the formation of a Ba-enriched (relative to bulk melt) meltphenocryst boundary layer, in which the bulk barium budget would come from partial dissolution of the same K-feldspar phenocryst and not from a new magma batch. In this case, only the thermal effect of the magma mixing process would be reflected in the K-feldspar texture and chemistry.

The K-feldspar phenocrysts of various types of granitoids within the RTB (i.e. PH and other localities) frequently exhibit one or more resorption surfaces and an equivalent number of Ba-enriched growth zones (Figs $2 \mathrm{a}-\mathrm{c}$ and 5). These textures imply discontinuous phenocryst growth, thermal disequilibria between the phenocryst and the surrounding melt and thus probably point to magma mixing. The limited role for magma mixing was also suggested by Zachariáśs (1998), on the basis of whole-rock Sr-Nd isotopic data. The core-to-rim decrease in the $\mathrm{Ba}$ content parallel both in the Ba-enriched zones and in the Ba-normal growth zones (Fig. 5c) allow us to suggest that the major process controlling the distribution of barium in the K-feldspar phenocrysts of the RTB granitoids was the fractional crystallization.

The above-mentioned discrepancy between the much higher Ba content in K-alteration-1 feldspars than in the groundmass feldspars of PH late-magmatic differentiates (i.e. aplite and leucogranodiorite) may therefore indicate that: i) K-alteration-1 is older than aplite/leucogranodiorite; or ii) the fluids responsible for K-alteration-1 scavenged the barium from deeper and less differentiated parts of the magma chamber.

\subsection{Magmatic vs hydrothermal biotite and amphibole}

The similar chemistry of the magmatic, metamorphic/recrystallized and early hydrothermal amphibole or biotite probably indicates temperature and chemical equilibrium between the $\mathrm{PH}$ granodiorite and early hydrothermal fluids. This could have resulted either from direct input of magmatic fluids into the hydrothermal-external fluid phase (as supported by fluid inclusion data, Zachariáš et al. 2001), or from a low water/rock ratio. Finally, the 
Tab. 3 Representative analyses of amphibole (wt. \% and recalculated on the basis of $23 \mathrm{O}+\mathrm{OH}$ )

\begin{tabular}{|c|c|c|c|c|c|c|c|c|c|c|c|}
\hline \multirow{3}{*}{$\begin{array}{l}\text { Rock*: } \\
\text { type: }\end{array}$} & GD per & \multicolumn{2}{|c|}{ GD cen } & GR per & GD cen & GD cen & \multicolumn{2}{|c|}{ biotite hornfels } & GD per & GD per & GD per \\
\hline & \multicolumn{3}{|c|}{ magmatic primary } & \multicolumn{3}{|c|}{ K-alteration-1 } & \multicolumn{2}{|c|}{ silicification-1 } & \multicolumn{3}{|c|}{ hornblende-2 veinlets } \\
\hline & \multicolumn{3}{|c|}{ amphibole-1 } & \multicolumn{3}{|c|}{ amphibole-3a } & \multicolumn{2}{|c|}{ amphibole-3a } & \multicolumn{3}{|c|}{ amphibole-3b } \\
\hline Sample & $23-28$ & $294-15$ & $294-37$ & $59-17$ & $201-42$ & $201-44$ & $219-27$ & $219-25$ & $23-41$ & $23-36$ & $23-21$ \\
\hline $\mathrm{SiO}_{2}$ & 50.58 & 50.98 & 51.14 & 45.07 & 50.62 & 51.97 & 49.68 & 52.26 & 47.33 & 47.91 & 48.91 \\
\hline $\mathrm{TiO}_{2}$ & 0.42 & 0.12 & 0.48 & 1.01 & 0.19 & 0.18 & 0.26 & 0.08 & 0.63 & 0.45 & 0.45 \\
\hline $\mathrm{Al}_{2} \mathrm{O}_{3}$ & 3.88 & 3.58 & 3.66 & 7.39 & 4.09 & 3.08 & 5.65 & 2.85 & 6.29 & 3.78 & 2.85 \\
\hline $\mathrm{Cr}_{2} \mathrm{O}_{3}$ & 0.05 & 0.03 & 0.05 & 0.03 & 0.00 & 0.02 & 0.00 & 0.00 & 0.00 & 0.07 & 0.17 \\
\hline $\mathrm{MnO}$ & 0.49 & 0.29 & 0.29 & 0.36 & 0.17 & 0.05 & 0.36 & 0.39 & 0.43 & 0.48 & 0.61 \\
\hline $\mathrm{FeO}_{\text {tot }}$ & 12.98 & 15.37 & 12.35 & 18.99 & 13.29 & 13.86 & 15.06 & 13.54 & 17.02 & 19.09 & 19.36 \\
\hline $\mathrm{MgO}$ & 15.20 & 14.23 & 15.87 & 11.12 & 15.59 & 15.55 & 13.89 & 15.46 & 11.34 & 11 & 10.48 \\
\hline $\mathrm{CaO}$ & 12.05 & 11.2 & 10.71 & 11.02 & 11.05 & 11.42 & 11.21 & 11.63 & 12.18 & 11.84 & 11.07 \\
\hline $\mathrm{Na}_{2} \mathrm{O}$ & 0.60 & 0.50 & 0.74 & 0.86 & 0.57 & 0.34 & 0.53 & 0.24 & 0.58 & 0.70 & 0.58 \\
\hline $\mathrm{K}_{2} \mathrm{O}$ & 0.31 & 0.26 & 0.38 & 0.90 & 0.31 & 0.32 & 0.27 & 0.20 & 0.53 & 0.33 & 0.30 \\
\hline Total & 96.56 & 96.56 & 95.67 & 96.75 & 95.88 & 96.79 & 96.91 & 96.65 & 96.33 & 95.65 & 94.78 \\
\hline $\mathrm{Si}$ & 7.352 & 7.395 & 7.380 & 6.710 & 7.305 & 7.460 & 7.165 & 7.517 & 7.095 & 7.282 & 7.474 \\
\hline $\mathrm{Al}^{\mathrm{IV}}$ & 0.648 & 0.605 & 0.620 & 1.290 & 0.695 & 0.521 & 0.835 & 0.483 & 0.905 & 0.677 & 0.513 \\
\hline $\mathrm{Ti}^{\mathrm{IV}}$ & 0.000 & 0.000 & 0.000 & 0.000 & 0.000 & 0.019 & 0.000 & 0.000 & 0.000 & 0.041 & 0.013 \\
\hline Sum T & 8.000 & 8.000 & 8.000 & 8.000 & 8.000 & 8.000 & 8.000 & 8.000 & 8.000 & 8.000 & 8.000 \\
\hline $\mathrm{Al}^{\mathrm{VI}}$ & 0.017 & 0.007 & 0.002 & 0.006 & 0.001 & 0.000 & 0.125 & 0.000 & 0.207 & 0.000 & 0.000 \\
\hline $\mathrm{Ti}^{\mathrm{VI}}$ & 0.046 & 0.013 & 0.052 & 0.113 & 0.021 & 0.000 & 0.028 & 0.009 & 0.071 & 0.011 & 0.039 \\
\hline $\mathrm{Zr}$ & 0.000 & 0.000 & 0.000 & 0.000 & 0.000 & 0.000 & 0.000 & 0.000 & 0.000 & 0.000 & 0.000 \\
\hline $\mathrm{Cr}$ & 0.006 & 0.003 & 0.006 & 0.004 & 0.000 & 0.002 & 0.000 & 0.000 & 0.000 & 0.008 & 0.021 \\
\hline $\mathrm{Fe}^{3+}$ & 0.548 & 0.882 & 0.901 & 1.093 & 0.997 & 0.837 & 0.970 & 0.765 & 0.371 & 0.515 & 0.553 \\
\hline $\mathrm{Mg}$ & 3.294 & 3.077 & 3.414 & 2.468 & 3.354 & 3.328 & 2.986 & 3.315 & 2.534 & 2.493 & 2.388 \\
\hline $\mathrm{Fe}^{2+}$ & 1.030 & 0.982 & 0.589 & 1.271 & 0.607 & 0.827 & 0.846 & 0.864 & 1.763 & 1.912 & 1.921 \\
\hline $\mathrm{Mn}^{2+}$ & 0.060 & 0.036 & 0.035 & 0.045 & 0.021 & 0.006 & 0.044 & 0.048 & 0.055 & 0.062 & 0.079 \\
\hline Sum C & 5.000 & 5.000 & 5.000 & 5.000 & 5.000 & 5.000 & 5.000 & 5.000 & 5.000 & 5.000 & 5.000 \\
\hline $\mathrm{Ca}$ & 1.876 & 1.740 & 1.656 & 1.758 & 1.708 & 1.756 & 1.732 & 1.792 & 1.956 & 1.928 & 1.812 \\
\hline $\mathrm{Na}$ & 0.124 & 0.141 & 0.207 & 0.242 & 0.159 & 0.095 & 0.148 & 0.067 & 0.044 & 0.072 & 0.172 \\
\hline Sum B & 2.000 & 1.881 & 1.863 & 2.000 & 1.868 & 1.851 & 1.880 & 1.859 & 2.000 & 2.000 & 1.984 \\
\hline $\mathrm{Na}$ & 0.046 & 0.000 & 0.000 & 0.006 & 0.000 & 0.000 & 0.000 & 0.000 & 0.125 & 0.134 & 0.000 \\
\hline $\mathrm{K}$ & 0.057 & 0.048 & 0.070 & 0.171 & 0.057 & 0.059 & 0.050 & 0.037 & 0.101 & 0.064 & 0.058 \\
\hline Sum A & 0.103 & 0.048 & 0.070 & 0.177 & 0.057 & 0.059 & 0.050 & 0.037 & 0.226 & 0.198 & 0.058 \\
\hline $\mathrm{MG} \#\left(\mathrm{Fe}^{2+}\right)$ & 76.180 & 75.806 & 85.283 & 66.009 & 84.680 & 80.094 & 77.926 & 79.326 & 58.981 & 56.597 & 55.412 \\
\hline $\mathrm{MG} \#\left(\mathrm{Fe}_{\mathrm{tot}}\right)$ & 67.615 & 62.273 & 69.614 & 51.076 & 67.653 & 66.670 & 62.184 & 67.059 & 54.294 & 50.674 & 49.112 \\
\hline
\end{tabular}

*Explanations: GD cen $=$ granodiorite central, GD per $=$ granodiorite peripheral

Sum $\mathrm{T}=$ tetrahedral site sum, Sum $\mathrm{O}=$ octahedral site sum; Sum A = A site sum;

$\mathrm{MG} \#\left(\mathrm{Fe}^{2+}\right)=100 \mathrm{Mg} /\left(\mathrm{Mg}+\mathrm{Fe}^{2+}\right)$, i.e. Fe recalculated to $\mathrm{Fe}^{2+}$ and $\mathrm{Fe}^{3+} ; \mathrm{MG}\left(\mathrm{Fe}_{\mathrm{tot}}\right)=100 \mathrm{Mg} /\left(\mathrm{Mg}^{+} \mathrm{Fe}_{\text {tot }}{ }^{2+}\right)$

similar chemistry indicates similar and rather stable conditions (mainly $\mathrm{fO}_{2}$ ) during formation of the magmatic and metamorphic/recrystallized amphiboles.

In porphyry systems, where early fluids expelled from the magma cause high-temperature potassic alteration, hydrothermal biotites usually exhibit much lower $\mathrm{Ti}$ contents and higher MG\# values compared to magmatic biotites. This is due to higher $\mathrm{fO}_{2}$ during the alteration processes (e.g. Chivas 1981). Similar trends were also found in the PH deposit but are much less noticeable.

Finally, relatively constant and high whole-rock $\mathrm{K}_{2} \mathrm{O}$ contents (Fig. 8) in granitoids from the $\mathrm{PH}$ area (c. 40 


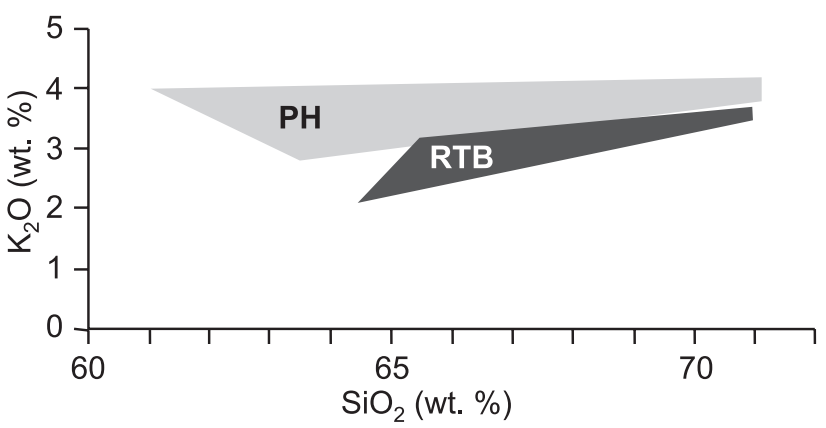

Fig. 8 Correlation between whole-rock $\mathrm{K}_{2} \mathrm{O}$ and $\mathrm{SiO}_{2}$ data in the mineralized granitoids of the Petráčkova hora deposit ( $\mathrm{PH}$; c. 40 analyses) and in similar but non-mineralized rocks of the Rožmitál tectonic block (RTB; c. 25 analyses), namely from the Trepanda and Voltuš areas.

analyses), compared to distinct positive $\mathrm{K}_{2} \mathrm{O}-\mathrm{SiO}_{2}$ correlation in similar non-mineralized rocks of the $\mathrm{RTB}$ (c. 25 analyses), might indicate the widespread presence of weak K-alteration in the $\mathrm{PH}$ deposit. On the other hand, although the PH and RTB intrusive rocks are very texturally and macroscopically similar, it cannot be guaranteed that they were originally (i.e. before alteration) compositionally totally identical (i.e. exhibited absolutely the same $\mathrm{K}_{2} \mathrm{O}-\mathrm{SiO}_{2}$ correlation).

\section{Conclusions}

The compositional similarity between the late magmatic and early hydrothermal K-feldspar, biotite and amphibole indicates temperature and chemical quasi-equilibrium between the host granodiorite and the early hydrothermal fluids. This could reflect either equilibration of mineralizing fluids with hot granitic masses at depth and/or direct admixture of an exsolved magmatic fluid phase in the hydrothermal fluids. Minerals and fluids associated with the main and late hydrothermal stages are out of equilibrium with magmatic and early hydrothermal assemblages.

Genetically, the most useful tool seems to be barium content in K-feldspar and consequently their internal structure seen by BSE imaging. Distribution of Ba in Kfeldspar phenocrysts and in the groundmass K-feldspars of the granodiorite and granodiorite porphyries in the $\mathrm{PH}$ and RTB is compatible with their magmatic nature and with the dominant role for fractional crystallization. In detail, however, the K-feldspar phenocrysts display more complex internal textures. Among them, the presence of resorption surfaces highlighted by Ba-rich overgrowth zones in phenocrysts indicates discontinuous magmatic crystallization and interplay of magma mixing. Finally, the higher Ba content in K-feldspars associated with early hydrothermal alteration (K-alteration-1) than in the late magmatic differentiates (aplite and leucogranodiorite; both older than K-alteration-1) may indicate that the barium came from deeper, and probably also more $\mathrm{Ba}-$ rich, parts of the $\mathrm{PH}$ magmatic chamber.

The minor difference in the composition of early hydrothermal biotite and amphibole (such as an increase in the $\mathrm{Mg} /\left(\mathrm{Mg}+\mathrm{Fe}^{2+}\right)$ ratio and a decrease in the Ti content $)$ compared to the magmatic phases is compatible with the data from mineralized porphyry systems worldwide.

Acknowledgments. This research was supported by the Czech Science Foundation, project No. 205/93/0991 and by the Ministry of Education grant MSM0021620855. The author would also like to thank to Blanka and Ivan Studničný (GMS a.s., Praha) for providing access to the exploration data, mine adit and for discussions. Useful reviews by J. Leichmann, L. Hecht, and critical comments by J. Konopásek are highly appreciated.

\section{References}

Anderson AT, Davis AM, Lu FQ (2000) Evolution of Bishop Tuff rhyolitic magma based on melt and magnetite inclusions and zoned phenocrysts. J Petrol 41: 449-473

BAKER T (2002) Emplacement depth and carbon dioxide-rich fluid inclusions in intrusion-related gold deposits. Econ Geol 97: 1111-1117

Cherniak DJ (2002) Ba diffusion in feldspar. Geochim Cosmochim Acta 66: 1641-1650

Chivas AR (1981) Geochemical evidence for magmatic fluids in porphyry copper mineralization. Part I. Mafic silicates from the Koloula igneous complex. Contrib Mineral Petrol 78: 389-403

Drozen J, RöHlich P, STUdniČNÁ B, STUdničnÝ I (1986) Volcanogenic facies of the Lower Cambrian in the Rožmitál tectonic block and its mineralization. Věst Ústř Úst geol 61: 265-272 (in Czech)

EsAwI EK (2004) AMPH-CLASS: An Excel spreadsheet for the classification and nomenclature of amphiboles based on the 1997 recommendations of the International Mineralogical Association. Comput and Geosci 30: 753-760

Gagnevin D, Daly JS, Poli G, Morgan D (2005) Microchemical and $\mathrm{Sr}$ isotopic investigation of zoned K-feldspar megacrysts: insights into petrogenesis of granitic system and disequilibrium crystal growth. J Petrol 46: 1689-1724

Goldfarb RJ, Groves DI, Gardoll S (2001): Orogenic gold and geologic time: a global synthesis. Ore Geol Rev 18: 1-75

GrAnt JA (1986) The Isocon diagram - a simple solution to Gresens' equation for metasomatic alteration. Econ Geol 81: 1976-1982

Gresens RL (1967) Composition-volume relationships of metasomatism. Chem Geol 2: 47-65 
HAVLíčEK V (1977) The Paleozoic (Cambrian-Devonian) in Rožmitál area. Věst Ústř Úst geol 52: 81-94

HAVLíčEK V (1992) Rožmitál Furrow. In: Chlupáč I (ed) Paleozoic of the Barrandian, Czech Geological Survey, Prague, pp 199-202 (In Czech)

Holub FV, Machart J, Manová M (1997) The Central Bohemian Plutonic Complex: Geology, chemical composition and genetic interpretation. Sborník geol věd, ložisk Geol Mineral 31: 27-50

JANOUŠEK V, WiEgAND B, ŽÁK J, ERBAN V (2007) Age, geotectonic setting and petrogenesis of Variscan calc-alkaline plutonism in Central Europe - examples from the Central Bohemian Plutonic Complex, Czech Republic. Géologie de la France 2007, 110

KETTNER R (1952) Geology of Třemšín unit and its surroundings. Věst Král čs spol nauk, trrída mat-přír 14: 1-21 (in Czech)

Kodym O jr, Suk M (1960) Summary of geology of western part of the Central Bohemian Pluton. Věstník Ústř Úst Geol 35: 269-277 (in Czech)

LANG JR, BAKER T (2001) Intrusion-related gold systems: the present level of understanding. Miner Depos 36: 477-489

Leake BE, Woolley AR, Arps CES, Birch WD, Gilbert MC, Grice JD, Hawthorne FC, Kato A, Kisch HJ, KrivoviCHEV VG, Linthout K, LAird J, Mandarino JA, Maresch WV, Nickel EH, Rock NMS, Schumacher JC, Smith DC, Stephenson NCN, Ungaretti L, Whittaker EJW, YouzHI G (1997) Nomenclature of amphiboles: report of the subcommittee on amphiboles of the international mineralogical association, commission on new minerals and mineral names. Mineral Mag 61: 295-321

Sмітн JV (1974) Feldspar Minerals Vol. 2. Springer-Verlag, Berlin, pp 1-690
Stimac JA, Pearce TH (1992) Textural evidence of maficfelsic magma interaction in dacite lavas, Clear Lake, California. Amer Miner 77: 795-809

STUdničnÁ B, StudničnÝ I (1995) Porphyry deposit with $\mathrm{Au}-\mathrm{Cu}-\mathrm{W}$ mineralization at Petráčkova hora Hill near Vacíkov. Uhlí, rudy, geologický průzkum 5: 142-146 (in Czech)

STUDNIČNÁ B, ZACHARIÁš J (1996) The porphyry ore deposit with $\mathrm{Au}-\mathrm{Cu}-\mathrm{W}$ mineralization on the Petráčkova hora Mt. near Vacíkov. In: Morávek P (ed) Gold deposits in Bohemia. Czech Geological Survey, Prague, pp 57-78

STUdničnÝ I, Studničná B, Hron M, VÁVra J, DvořÁK J, Koroš I, Drozen J, Pertoldová J, Šulcová V, Žáček M (1987) Final report: Rožmitál area: $\mathrm{Au}(\mathrm{Cu}, \mathrm{W})$ prospection, project No. 0179 2105. Unpubl. Report, Geofond ČR (P56554), Prague, (in Czech)

Studničný I, Studničná B, Hron M, Toula J, VÁvra J, Kučera R, Dvořák J, Koroš I, Drozen J, Fediuk F, Pertoldová J, Šulcová V, Žáček M, Havlíček S, BurSíKOVÁ I, Jurák I, KaVALEC J (1994) Final report: Vacíkov - project No. 2988 2101. Unpubl. Report, Geofond ČR (FZ 6423), Prague, (in Czech)

VERNON RH (1986) K-feldspar megacrysts in granites - phenocrysts, not porphyroblasts. Earth Sci Rev 23: 1-63

ZACHARIÁŠ J (1998) High-temperature Au-porphyry style deposit "Vacíkov-Petráčkova hora" near Rožmitál pod Třemšínem - complex genetic study. Unpublished $\mathrm{PhD}$. Thesis, Faculty of Science, Charles University, Prague, pp 1-259

Zachariáš J, Pertold Z, Pudilová M, Žák K, Pertoldová J, Stein H, Markey R (2001) Geology and genesis of Variscan porphyry-style gold mineralization, Petráčkova hora deposit, Bohemian Massif, Czech Republic. Miner Depos 36: 517-541 